\title{
Aeolian Carbon Salts in the Taklamakan and Badanjilin Deserts in Northwestern China and Their Potential Role in Global Carbon Cycle
}

\author{
Bing-Qi Zhu \\ Key Laboratory of Water Cycle and Related Land Surface Processes, Institute of Geographic Sciences and Natural Resources Research, \\ Chinese Academy of Sciences, Beijing, China
}

Email address:

To cite this article:

Bing-Qi Zhu. Aeolian Carbon Salts in the Taklamakan and Badanjilin Deserts in Northwestern China and Their Potential Role in Global Carbon Cycle. American Journal of Biological and Environmental Statistics. Vol. 3, No. 2, 2017, pp. 26-35. doi: 10.11648/j.ajbes.20170302.12

Received: January 13, 2017; Accepted: January 31, 2017; Published: November 1, 2017

\begin{abstract}
Previous studies have suggested that a significant loop in the carbon cycle may be hidden in the global desert areas (both low latitude and middle latitude). Due to the complexity of salt formation involved in atmosphere-landscape relation, there are few study involved into the pool of secondary carbonates in world desert soils, particularly in arid areas in northern China. Large sandy deserts in the middle latitudes of northwestern China were investigated in this study. The physical and geochemical examinations are carried out into soluble carbon salts in modern and ancient dune sediments from the inland deserts in northwestern China, with the aim to explore the composition of carbon salts in aeolian sediments and their possible environmental implications for global carbon cycle. The results show that the aeolian salt has high alkalinities, which are mainly determined by evaporitic alkaline earth carbonates. The carbonates are secondary salt in origin and are possibly introduced from the atmosphere into the pedosphere by a carbon-fixation process. Owing to the high capability to neutralize atmospheric carbonic acid, large desert area, and the strong potential of carbonate preservation in soil under arid climate, the middle-latitude Chinese deserts can be potentially qualified as a significant contributor to the global carbon cycle. But the low-latitude deserts in tropic areas may be not able to provide such a contribution.
\end{abstract}

Keywords: Global Carbon Cycle, Evaporitic Carbon Salt, Aeolian Sediment, Carbon-Fixation Process, Middle-Latitude Desert, Northwestern China

\section{Introduction}

Soil inorganic carbon (SIC), with a global reservoir of approximately $940 \mathrm{Pg}[1]$, is one of the three major components (SIC, SOC and ocean reservoirs) of the global C pool. The SIC pool is primarily located in soils of the arid regions which contain several times (2 to 5) more SIC than SOC [2].

In desert areas, soil carbonate- $\mathrm{C}$ is the dominant type of $\mathrm{C}$ stored in soil [3]. The SIC pool includes lithogenic carbon (LIC) and pedogenic carbon (PIC), the latter also being termed the secondary carbonates [2]. PIC is the major component of SIC in soil under the arid environment [2]. This secondary carbonates (PIC) may be formed through the decomposition/dissolution of LIC or carbonate bearing minerals and reprecipitation of weathering products, or through precipitation of atmospheric $\mathrm{CO}_{2}$ with $\mathrm{Ca}^{2+}$ and $\mathrm{Mg}^{2+}$ on other salts in soils [4]. Because of the complexity of these processes involved in atmosphere-landscape relation, there are few reliable estimates of the pool of secondary carbonates in world desert soils $[5,6,7,8,9,10]$, particularly in arid areas in northern China [11, 12, 13, 14, 15, 16, 17].

The global carbon balance includes a large terrestrial carbon sink, but that sink has not been fully identified nor its mechanisms explained $[18,19,20,21,22,23]$. Recent findings that desert regions remove carbon dioxide $(\mathrm{CO} 2)$ from the atmosphere at a magnitude of $\sim 100 \mathrm{~g} \mathrm{Cm}^{-2} \mathrm{yr}^{-1}$ suggest that these systems may explain at least a portion of that terrestrial carbon sink [23, 24, 25, 26, 27, 28]. Stone (2008) [25] suggests that a significant loop in the carbon cycle may be 
hidden in the global desert areas (both low latitude and middle latitude), because two of the northern middle-latitude deserts, the Gulbantonggut Desert of northwestern China [27] and the Mojave Desert of western USA [26], were both observed to be soaking up the surrounding $\mathrm{CO}_{2}$ in an inorganic-salt form at a surprising rate.

Recent studies [15, 29, 30, 31, 32, 33, 35] have reported that the total SIC storage in China, approximately 55.3 $\pm 10.7 \mathrm{Pg} \mathrm{C}$ with a current average content of $6.3 \pm 1.2 \mathrm{~kg} / \mathrm{m}^{2} \mathrm{C}$ in surface soil layers (including both organic - A horizon - and mineral horizons $-\mathrm{B}$ and $\mathrm{C}$ horizons), representing $5.8 \%$ of the global SIC pool [15], is experiencing great variation. For example, approximately $51 \%$ of total cultivated soil surfaces in China have experienced $\mathrm{C}$ loss where the most significant loss has been observed in the eastern part of northern China in dry farmlands as well as irrigated soils and paddy soils. On the contrary, SIC has increased $(\sim 10 \%)$ in irrigated soils in northwestern China. These evaluations, however, to a great extent are based on farmlands, irrigated lands or grassland without consideration of sandy desert areas which together account for about a fourth of China's land mass.

In this work we present a physical and geochemical exploration into soluble carbon-bearing salts in sandy dunes from the inland deserts (such as the Taklamakan and the Badanjilin Deserts) in northwestern China, representing a cross-section of different environments (from westerly to monsoon climate control) in the middle-latitudes of the Northern Hemisphere (NH). The objectives of this paper were to explore the composition and distribution of evaporitic carbon salts in aeolian sediments and their possible environmental implications for global carbon cycle.

\section{Methodology}

The study areas and sampling sites were chosen from large sand seas in northwestern China (Fig. 1a), i.e., the Taklamakan Desert (the westerly climate control) and the Badanjilin Desert (the monsoon climate control). Both the modern and ancient aeolian sediments were designed to be sampled in the field. For modern aeolian sediment, thirty-three dunes in the Taklamakan Desert and fourteen dunes in the Badanjilin Desert were sampled in this study. The modern samples were mainly collected from the surface of active dunes, geographically located in the center and southern edge of the Taklamakan (Fig. 1b), and from the southern part of the Badanjilin (Fig. 1c-d).

After removing coarse plant fragments, $15 \mathrm{~g}$ of sediment were weighted from each bulk sample. In the laboratory, samples were mixed with $75 \mathrm{~g}$ of deionized water to produce water-soil solutions. The solutions were allowed to settle for
$24 \mathrm{~h}$ and then vibrated for $5 \mathrm{~min}$ in an ultrasonic-wave oscillator at room temperature to leach the water-soluble salts from the solid phase of the samples. After oscillation, the leachate was extracted and filtered through a PTFE membrane using a Millipore syringe (with a pore size of $0.45 \mu \mathrm{m}$ ). The leachate extraction was then prepared for analysis. The parameters measured in this analysis include temperature $(\mathrm{T})$, $\mathrm{pH}$, electrical conductivity (EC), oxidation-reduction potential (Eh), total dissolved solid (TDS), major cations ( $\mathrm{Li}$, $\mathrm{Na}, \mathrm{NH}_{4}, \mathrm{~K}, \mathrm{Mg}, \mathrm{Ca}$ ) and major anions ( $\mathrm{F}, \mathrm{Cl}, \mathrm{Br}, \mathrm{NO}_{2}, \mathrm{NO}_{3}$, $\mathrm{H}_{2} \mathrm{PO}_{4}, \mathrm{SO}_{4}$ and $\mathrm{HCO}_{3}+\mathrm{CO}_{3}$ ). Major ionic concentrations were measured using ion chromatography (IC, Dionex 600) following the manufacturer's manual. An AS11 analytical column, $\mathrm{Na}_{2} \mathrm{CO}_{3}$ and $\mathrm{NaHCO}_{3}$ eluent and $100 \mu \mathrm{l}$ sample loop were employed for the determinations of anions. The cations were determined by IC with a CS12A analytical column and a $25 \mu 1$ sample loop, with methanesulphonic acid (MSA) as the eluent. The detection limit for major anions and cations is $<0.1$ $\mathrm{mg} / \mathrm{l}$ and the error of the analytical procedures is $\pm 2 \%$. The $\mathrm{T}$, $\mathrm{pH}, \mathrm{EC}, \mathrm{Eh}$, and TDS were measured with a Multi-Parameter Analyzer (Eijkelkamp 18.28). The TDS is calculated based on electrical conductivity (EC) and temperature (T) and by a standard calculation implemented in the Eijkelkamp 18.28 analyzer. The used formula was TDS $=0.6452 \times \mathrm{EC}_{\mathrm{T}} /(1+$ $0.02 \times \Delta \mathrm{t})\left(\mathrm{r}^{2}=0.99\right)$, where $\Delta \mathrm{t}=\mathrm{T}-25^{\circ} \mathrm{C}$. The error of the analytical procedures was $<2 \%$ for $\mathrm{pH}$ and $\mathrm{Eh},<1 \%$ for $\mathrm{EC}$ and TDS. Alkalinity was measured using Gran's method [36]. Based on the TDS and the water and soil mass quantity, the total salt content to total sample mass was calculated, and it is referred here as the "salinity" of the sample. To explore the relationship between the salt concentration and particle size distribution, some dune surface samples were selected for particle size analysis (PSA). Thirty grams of sediment from each sample was dry sieved at $0.25 \phi$ intervals with measurement ranging from 38 to $2,360 \mu \mathrm{m}$ by a three-dimensional vibration sieving machine (Retsch AS200 Grain-size Analyzers). Soil-water extractions of several selected particle-size fractions of these samples were also measured for physical data using the methods stated above. Detailed analytical methods for soluble salt geochemistry of aeolian sediment samples can also be seen from Zhu and Yang (2010) [16]. The physical and chemical analytical data of the soluble salt compositions of sediments are shown in Table 1 and Table 2, respectively. Partial characteristics of aeolian salts from the Taklamakan and Badanjilin Deserts were previously reported in our early works [16, 17] with preliminary descriptions of their composition and distribution, but the characteristics of evaporitic carbonates in aeolian sediments and their environmental significance are presented here along with the salt origin estimations. 

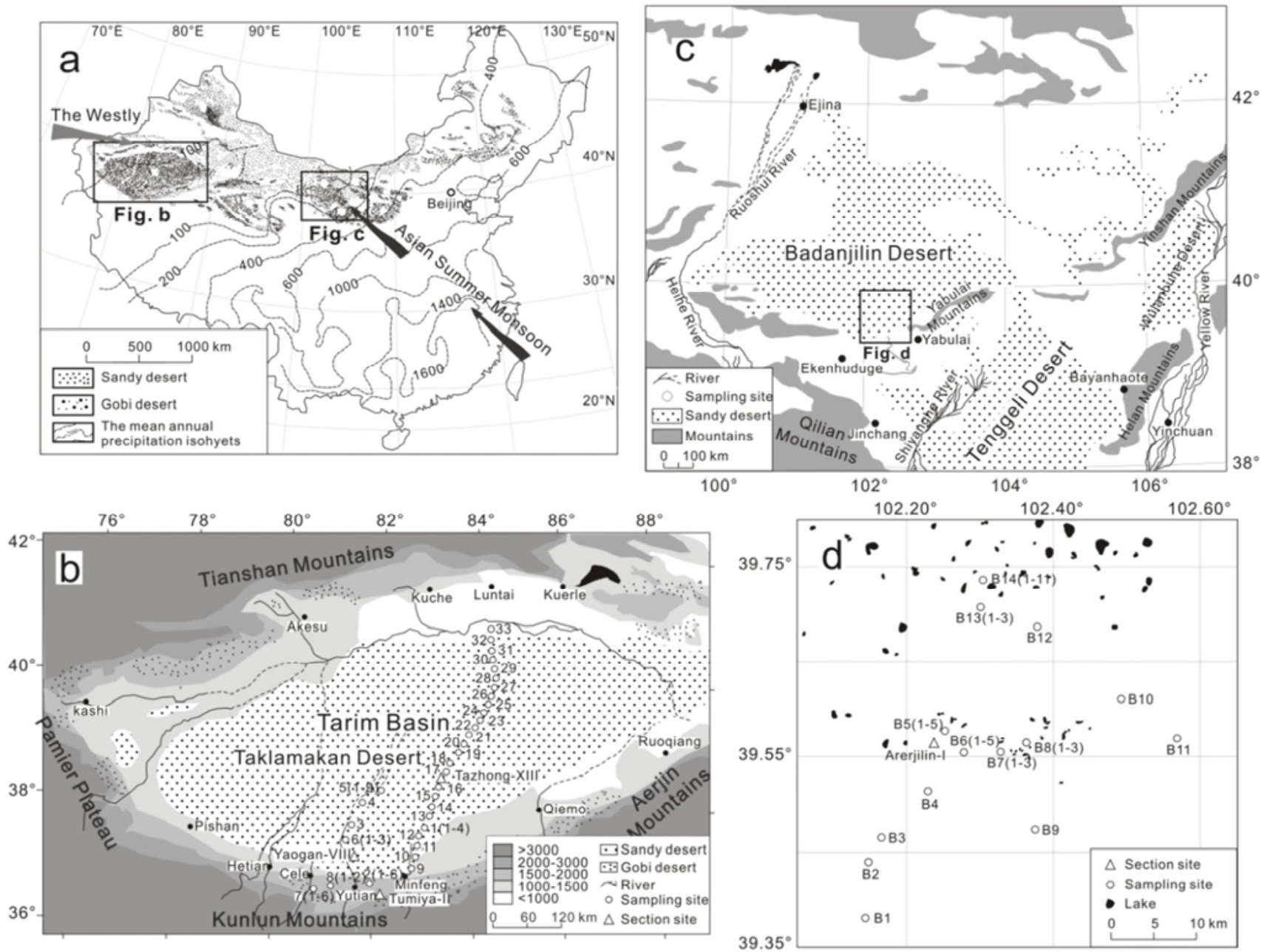

Figure 1. Locations of the study areas and sampling sites in this study. (a) The distributions of deserts and the mean annual precipitation isohyets in China, (b) the Taklamakan Desert, (c) and (d) the Badanjilin Desert.

Table 1. Physical parameters of the soil-water extraction of the modern and ancient aeolian sediments from the Taklamakan and Badanjilin deserts in northwestern China.

\begin{tabular}{|c|c|c|c|c|c|c|c|c|c|c|c|}
\hline $\begin{array}{l}\text { Sample } \\
\text { name }\end{array}$ & $\mathbf{p H}$ & $\operatorname{Eh}(\mathbf{m V})$ & $\begin{array}{l}\text { EC } \\
(\mu \mathrm{S} / \mathrm{cm})\end{array}$ & $\begin{array}{l}\text { TDS } \\
(\mathrm{mg} / \mathrm{L})\end{array}$ & Salinity (\%o) & $\begin{array}{l}\text { Sample } \\
\text { name }\end{array}$ & pH & Eh $(\mathbf{m V})$ & $\begin{array}{l}\mathrm{EC} \\
(\mu \mathrm{S} / \mathrm{cm})\end{array}$ & $\begin{array}{l}\text { TDS } \\
(\mathrm{mg} / \mathrm{L})\end{array}$ & $\begin{array}{l}\text { Salinity } \\
(\%)\end{array}$ \\
\hline \multicolumn{12}{|c|}{ The dune-surface sand samples collected from the Badanjilin Desert } \\
\hline B1 & 9.20 & -141 & 73.6 & 39.1 & 0.197 & B2 & 9.10 & -145 & 49.4 & 26.3 & 0.134 \\
\hline B3 & 9.01 & -140 & 39.2 & 20.8 & 0.104 & B4 & 9.23 & -143 & 35.0 & 18.6 & 0.096 \\
\hline B5-1 & 9.13 & -139 & 33.0 & 17.6 & 0.088 & B5-2 & 8.97 & -131 & 51.6 & 27.5 & 0.137 \\
\hline B5-3 & 9.13 & -139 & 36.9 & 19.6 & 0.098 & B5-4 & 9.21 & -143 & 43.7 & 23.3 & 0.117 \\
\hline B5-5 & 8.82 & -129 & 42.9 & 22.9 & 0.114 & B6-1 & 9.11 & -145 & 42.7 & 22.7 & 0.116 \\
\hline B6-2 & 8.94 & -129 & 29.7 & 15.8 & 0.079 & B6-3 & 9.30 & -148 & 48.0 & 25.5 & 0.128 \\
\hline B6-4 & 9.35 & -151 & 55.0 & 29.3 & 0.146 & B6-5 & 8.99 & -138 & 157 & 83.0 & 0.414 \\
\hline B7-1 & 8.82 & -123 & 22.0 & 11.7 & 0.059 & B7-2 & 9.17 & -141 & 33.9 & 18.1 & 0.091 \\
\hline B7-3 & 9.35 & -151 & 62.5 & 33.2 & 0.167 & B8-1 & 8.85 & -122 & 21.9 & 11.6 & 0.059 \\
\hline B8-2 & 9.05 & -132 & 26.1 & 13.9 & 0.070 & B8-3 & 9.42 & -154 & 48.9 & 26.0 & 0.131 \\
\hline B9 & 8.98 & -137 & 37.8 & 20.3 & 0.102 & B10 & 9.05 & -140 & 43.8 & 23.5 & 0.117 \\
\hline B11 & 9.05 & -141 & 42.9 & 22.8 & 0.115 & B12 & 9.00 & -132 & 80.2 & 42.6 & 0.213 \\
\hline B13-1 & 9.00 & -138 & 32.3 & 17.2 & 0.086 & B13-2 & 9.10 & -143 & 72.9 & 38.8 & 0.194 \\
\hline B13-3 & 8.91 & -134 & 33.1 & 17.6 & 0.088 & B14-1 & 8.84 & -128 & 36.5 & 19.4 & 0.098 \\
\hline B14-2 & 9.20 & -148 & 41.6 & 22.2 & 0.112 & B14-3 & 9.22 & -150 & 49.1 & 26.1 & 0.132 \\
\hline B14-4 & 9.22 & -151 & 159 & 84.0 & 0.421 & B14-5 & 9.37 & -159 & 93.1 & 49.6 & 0.248 \\
\hline B14-6 & 9.13 & -146 & 76.0 & 40.4 & 0.203 & B14-7 & 9.21 & -149 & 97.4 & 51.7 & 0.261 \\
\hline B14-8 & 9.17 & -150 & 76.7 & 40.7 & 0.206 & B14-9 & 9.26 & -153 & 57.0 & 30.3 & 0.152 \\
\hline B14-10 & 9.36 & -160 & 126 & 67.0 & 0.336 & B14-11 & 9.26 & -154 & 52.7 & 28.0 & 0.140 \\
\hline \multicolumn{12}{|c|}{ The dune-surface sand samples collected from the Taklamakan Desert } \\
\hline T1-1 & 9.33 & -157 & 215 & 114 & 0.575 & T1-2 & 9.42 & -163 & 177 & 94 & 0.472 \\
\hline $\mathrm{T} 2-1$ & 9.37 & -158 & 115 & 61 & 0.311 & $\mathrm{~T} 2-2$ & 9.28 & -155 & 122 & 65 & 0.329 \\
\hline
\end{tabular}




\begin{tabular}{|c|c|c|c|c|c|c|c|c|c|c|c|}
\hline $\begin{array}{l}\text { Sample } \\
\text { name }\end{array}$ & $\mathbf{p H}$ & Eh $(\mathrm{mV})$ & $\begin{array}{l}\mathrm{EC} \\
(\mu \mathrm{S} / \mathrm{cm})\end{array}$ & $\begin{array}{l}\text { TDS } \\
(\mathrm{mg} / \mathrm{L})\end{array}$ & Salinity (\%o) & $\begin{array}{l}\text { Sample } \\
\text { name }\end{array}$ & pH & Eh $(\mathrm{mV})$ & $\begin{array}{l}\text { EC } \\
(\mu \mathrm{S} / \mathrm{cm})\end{array}$ & $\begin{array}{l}\text { TDS } \\
(\mathrm{mg} / \mathrm{L})\end{array}$ & $\begin{array}{l}\text { Salinity } \\
\text { (\%o) }\end{array}$ \\
\hline $\mathrm{T} 2-3$ & 9.44 & -163 & 118 & 62 & 0.310 & $\mathrm{~T} 2-4$ & 9.26 & -154 & 104 & 55 & 0.277 \\
\hline $\mathrm{T} 2-5$ & 9.21 & -151 & 255 & 135 & 0.682 & $\mathrm{~T} 3$ & 9.14 & -148 & 643 & 342 & 1.712 \\
\hline T4 & 9.37 & -159 & 406 & 216 & 1.090 & T5-1 & 9.33 & -158 & 826 & 439 & 2.214 \\
\hline T5-2 & 9.38 & -160 & 160 & 85 & 0.429 & T5-3 & 9.17 & -149 & 950 & 500 & 2.531 \\
\hline T6-1 & 9.47 & -166 & 699 & 372 & 1.864 & T9 & 9.47 & -164 & 326 & 173 & 0.868 \\
\hline $\mathrm{T} 10$ & 9.51 & -160 & 151 & 80 & 0.400 & $\mathrm{~T} 11$ & 9.26 & -152 & 290 & 154 & 0.775 \\
\hline T12 & 9.33 & -158 & 192 & 103 & 0.519 & $\mathrm{~T} 13$ & 8.77 & -125 & 645 & 347 & 1.754 \\
\hline T14 & 9.25 & -153 & 257 & 136 & 0.681 & $\mathrm{~T} 15$ & 9.29 & -154 & 259 & 138 & 0.695 \\
\hline T16 & 9.22 & -151 & 409 & 218 & 1.094 & $\mathrm{~T} 17$ & 9.10 & -148 & 318 & 169 & 0.846 \\
\hline T18 & 9.23 & -144 & 554 & 295 & 1.474 & $\mathrm{~T} 19$ & 8.99 & -141 & 307 & 163 & 0.815 \\
\hline $\mathrm{T} 20$ & 9.01 & -143 & 237 & 126 & 0.631 & $\mathrm{~T} 21$ & 9.25 & -153 & 398 & 212 & 1.063 \\
\hline T22 & 9.07 & -143 & 403 & 214 & 1.074 & $\mathrm{~T} 23$ & 9.16 & -150 & 186 & 99 & 0.497 \\
\hline $\mathrm{T} 24$ & 9.24 & -152 & 351 & 189 & 0.948 & $\mathrm{~T} 25$ & 8.91 & -137 & 311 & 165 & 0.831 \\
\hline T26 & 8.87 & -135 & 323 & 174 & 0.877 & $\mathrm{~T} 27$ & 8.89 & -135 & 223 & 119 & 0.598 \\
\hline T28 & 8.66 & -108 & 310 & 163 & 0.826 & T29 & 9.11 & -149 & 385 & 205 & 1.024 \\
\hline T30 & 9.32 & -160 & 172 & 91 & 0.455 & T31 & 9.33 & -161 & 210 & 112 & 0.562 \\
\hline T32 & 9.38 & -160 & 127 & 67 & 0.339 & T33 & 9.54 & -170 & 164 & 87 & 0.437 \\
\hline \multicolumn{12}{|c|}{ The buried sand (palaeo-sand) samples in the Taklamakan Desert } \\
\hline $\mathrm{T} 1-3$ & 9.53 & -168 & 150 & 80 & 0.400 & $\mathrm{~T} 1-4$ & 9.55 & -170 & 333 & 176 & 0.880 \\
\hline $\mathrm{T} 2-6$ & 9.33 & -158 & 406 & 216 & 1.086 & T5-4 & 9.19 & -150 & 667 & 355 & 1.779 \\
\hline T5-5 & 9.04 & -142 & 1130 & 600 & 3.019 & T5-6 & 9.24 & -150 & 581 & 309 & 1.563 \\
\hline T5-7 & 9.61 & -173 & 112 & 59 & 0.297 & T5-8 & 8.97 & -137 & 1210 & 640 & 3.215 \\
\hline T5-9 & 9.02 & -139 & 1010 & 540 & 2.721 & T6-2 & 9.21 & -151 & 2290 & 1230 & 6.171 \\
\hline T6-3 & 8.75 & -124 & 1240 & 660 & 3.317 & T8-1 & 8.82 & -128 & 1390 & 740 & 3.737 \\
\hline T8-2 & 8.65 & -118 & 2800 & 1500 & 7.542 & T7-1 & 8.54 & -112 & 6300 & 3420 & 17.15 \\
\hline T7-2 & 8.50 & -109 & 75300 & 49000 & 403.5 & T7-3 & 8.19 & -92 & 94400 & 63100 & 383.6 \\
\hline T7-4 & 8.52 & -109 & 6840 & 3710 & 18.63 & T7-5 & 8.70 & -121 & 4120 & 2240 & 11.29 \\
\hline T7-6 & 8.74 & -122 & 4580 & 2500 & 12.62 & & & & & & \\
\hline \multicolumn{12}{|c|}{ the Arerjilin-I section in the Badanjilin Desert } \\
\hline Ar1 & 9.09 & -135 & 428 & 228 & 1.156 & Ar2 & 9.73 & -174 & 492 & 262 & 1.313 \\
\hline Ar3 & 9.83 & -180 & 267 & 142 & 0.711 & Ar4 & 9.64 & -169 & 526 & 280 & 1.410 \\
\hline Ar5 & 9.46 & -157 & 678 & 361 & 1.811 & Ar6 & 9.31 & -149 & 684 & 364 & 1.827 \\
\hline Ar7 & 7.62 & -53 & 833 & 443 & 2.213 & Ar8 & 7.68 & -55 & 496 & 264 & 1.321 \\
\hline Ar9 & 7.42 & -41 & 1780 & 950 & 4.788 & Ar10 & 8.84 & -124 & 900 & 480 & 2.396 \\
\hline Ar11 & 7.60 & -51 & 264 & 140 & 0.699 & Ar12 & 7.74 & -60 & 291 & 155 & 0.772 \\
\hline Ar13 & 8.24 & -88 & 137 & 73.0 & 0.365 & & & & & & \\
\hline \multicolumn{12}{|c|}{ the Tazhong-XIII section in the Taklamakan Desert } \\
\hline Ta1 & 9.14 & -151 & 217 & 115 & 0.577 & $\mathrm{Ta} 2$ & 8.21 & -92 & 5550 & 3010 & 15.09 \\
\hline $\mathrm{Ta} 3$ & 8.47 & -111 & 906 & 482 & 2.424 & Ta4 & 8.04 & -84 & 5340 & 2890 & 14.58 \\
\hline Ta5 & 9.02 & -141 & 523 & 278 & 1.392 & Ta6 & 8.75 & -123 & 980 & 520 & 2.609 \\
\hline \multicolumn{12}{|c|}{ the Yaogan-VIII section in the Taklamakan Desert } \\
\hline Ya1 & 8.28 & -96 & 16200 & 9100 & 46.29 & Ya2 & 8.68 & -119 & 4350 & 2350 & 11.71 \\
\hline Ya3 & 8.77 & -126 & 2840 & 1520 & 7.576 & Ya4 & 8.83 & -128 & 4080 & 2200 & 11.14 \\
\hline Ya5 & 9.07 & -141 & 2070 & 1110 & 5.617 & Ya6 & 8.58 & -114 & 6830 & 3700 & 18.67 \\
\hline Ya7 & 8.24 & -94 & 41200 & 25000 & 125.27 & Ya8 & 8.71 & -121 & 29200 & 17100 & 86.53 \\
\hline Ya9 & 8.30 & -97 & 59800 & 37900 & 191.01 & Ya10 & 8.49 & -109 & 6390 & 3460 & 17.39 \\
\hline Ya11 & 8.80 & -127 & 6270 & 3400 & 17.19 & Ya12 & 9.06 & -141 & 768 & 409 & 2.062 \\
\hline Ya13 & 9.39 & -161 & 294 & 156 & 0.786 & & & & & & \\
\hline \multicolumn{12}{|c|}{ the Tumiya-II section in the Taklamakan Desert } \\
\hline Tu1 & 8.64 & -117 & 2860 & 1540 & 7.754 & Tu2 & 9.18 & -148 & 1010 & 530 & 2.669 \\
\hline Tu3 & 8.63 & -118 & 2880 & 1540 & 7.747 & Tu4 & 8.71 & -122 & 3920 & 2110 & 10.64 \\
\hline Tu5 & 8.77 & -125 & 4250 & 2310 & 11.87 & Tu6 & 8.51 & -109 & 1080 & 590 & 2.963 \\
\hline $\mathrm{Tu} 7$ & 9.56 & -170 & 1410 & 750 & 3.797 & Tu8 & 9.53 & -170 & 2000 & 1070 & 5.422 \\
\hline Tu9 & 9.18 & -149 & 8490 & 4640 & 23.23 & Tu10 & 9.35 & -157 & 3250 & 1750 & 8.740 \\
\hline Tu11 & 9.45 & -165 & 3570 & 1920 & 9.911 & Tu12 & 9.52 & -168 & 1330 & 710 & 3.562 \\
\hline Tu13 & 9.48 & -164 & 1410 & 750 & 3.836 & Tu14 & 9.52 & -169 & 1740 & 930 & 4.670 \\
\hline Tu15 & 9.62 & -174 & 723 & 384 & 1.947 & Tu16 & 9.50 & -168 & 805 & 428 & 2.154 \\
\hline Tu17 & 9.72 & -180 & 446 & 238 & 1.207 & Tu18 & 9.66 & -176 & 413 & 220 & 1.108 \\
\hline Tu19 & 9.66 & -175 & 842 & 447 & 2.245 & $\mathrm{Tu} 20$ & 9.94 & -192 & 221 & 117 & 0.591 \\
\hline Tu21 & 9.65 & -174 & 960 & 510 & 2.573 & Tu22 & 9.46 & -166 & 663 & 353 & 1.786 \\
\hline Tu23 & 8.64 & -116 & 1570 & 840 & 4.225 & Tu24 & 9.68 & -178 & 608 & 322 & 1.628 \\
\hline Tu25 & 9.18 & -149 & 1440 & 770 & 3.866 & Tu26 & 9.12 & -145 & 2010 & 1080 & 5.401 \\
\hline Tu27 & 9.73 & -180 & 573 & 305 & 1.535 & Tu28 & 8.69 & -119 & 2380 & 1270 & 6.471 \\
\hline Tu29 & 9.66 & -175 & 840 & 447 & 2.261 & & & & & & \\
\hline
\end{tabular}


Table 2. The analytical data of major ionic compositions for the soil-water extraction of the aeolian sediments from the Taklamakan and Badanjilin deserts.

\begin{tabular}{|c|c|c|c|c|c|c|c|}
\hline Sample name & $\mathrm{Na}^{+}(\mathrm{mg} / \mathrm{l})$ & $\mathrm{K}^{+}(\mathrm{mg} / \mathrm{l})$ & $\mathrm{Mg}^{2+}(\mathrm{mg} / \mathrm{l})$ & $\mathrm{Ca}^{2+}(\mathrm{mg} / \mathrm{l})$ & $\mathrm{Cl}^{-}(\mathrm{mg} / \mathrm{l})$ & $\mathrm{SO}_{4}{ }^{2-}(\mathrm{mg} / \mathrm{l})$ & $\mathrm{HCO}_{3}^{-}(\mathrm{mg} / \mathrm{l})$ \\
\hline B1 & 4.30 & 3.66 & 0.46 & 2.03 & 7.62 & 1.53 & 13.0 \\
\hline B3 & 2.53 & 1.81 & 0.32 & 1.82 & 2.74 & 0.50 & 8.39 \\
\hline B4 & 10.0 & 1.37 & 0.28 & 1.23 & 2.87 & 0.53 & 0.46 \\
\hline B5-1 & 3.85 & 1.68 & 0.38 & 1.44 & 1.32 & 0.90 & 4.99 \\
\hline B5-2 & 3.91 & 2.80 & 0.50 & 2.03 & 6.99 & 1.61 & 4.25 \\
\hline B5-3 & 6.07 & 3.22 & 0.33 & 1.63 & 2.10 & 1.16 & 1.30 \\
\hline B5-4 & 5.71 & 3.54 & 0.36 & 1.67 & 1.67 & 1.11 & 5.78 \\
\hline B6-2 & 5.11 & 3.22 & 0.35 & 1.24 & 1.69 & 0.80 & 0.77 \\
\hline B6-3 & 3.62 & 2.04 & 0.42 & 2.04 & 7.12 & 1.21 & 5.39 \\
\hline B7-1 & 2.80 & 1.19 & 0.27 & 0.81 & 2.12 & 0.67 & 2.08 \\
\hline B7-2 & 2.99 & 1.27 & 0.34 & 1.85 & 1.63 & 0.42 & 7.00 \\
\hline B7-3 & 3.71 & 2.75 & 0.38 & 2.13 & 1.64 & 1.20 & 17.5 \\
\hline B8-1 & 4.16 & 1.32 & 0.77 & 1.35 & 4.33 & 1.76 & 1.90 \\
\hline B8-2 & 3.79 & 1.06 & 0.34 & 1.28 & 2.90 & 0.96 & 0.98 \\
\hline B8-3 & 3.64 & 1.59 & 0.45 & 2.01 & 5.44 & 0.66 & 9.08 \\
\hline B10 & 9.45 & 1.37 & 0.24 & 0.88 & 4.60 & 0.91 & 4.01 \\
\hline B11 & 3.77 & 1.24 & 0.43 & 1.67 & 3.70 & 0.31 & 8.58 \\
\hline B12 & 4.48 & 4.18 & 0.70 & 4.13 & 2.05 & 1.67 & 17.5 \\
\hline T1-1 & 20.7 & 2.77 & 0.65 & 2.49 & 45.1 & 0.77 & 33.5 \\
\hline T1-3 & 15.6 & 1.09 & 0.59 & 1.55 & 19.6 & 1.33 & 34.4 \\
\hline $\mathrm{T} 2-4$ & 6.84 & 2.05 & 0.67 & 2.36 & 10.9 & 2.74 & 22.3 \\
\hline $\mathrm{T} 2-5$ & 21.4 & 3.34 & 0.57 & 2.43 & 49.4 & 4.51 & 38.5 \\
\hline $\mathrm{T} 3$ & 62.0 & 6.97 & 1.25 & 4.21 & 162 & 9.46 & 68.8 \\
\hline $\mathrm{T} 4$ & 43.9 & 6.03 & 0.91 & 2.42 & 89.4 & 1.72 & 53.1 \\
\hline T5-3 & 107 & 9.48 & 1.01 & 3.67 & 257 & 3.35 & 80.8 \\
\hline T5-4 & 72.9 & 9.26 & 1.47 & 4.44 & 178 & 6.06 & 52.4 \\
\hline T5-8 & 125 & 14.6 & 2.70 & 9.57 & 331 & 14.7 & 96.0 \\
\hline T7-2 & 10375 & 234 & 26.3 & 325.4 & 15091 & 1699 & 19203 \\
\hline $\mathrm{T} 7-3$ & 9255 & 117 & 11.2 & 293 & 23841 & 2013 & 12419 \\
\hline T10 & 16.8 & 3.77 & 0.56 & 3.08 & 24.1 & 4.01 & 17.3 \\
\hline T18 & 55.3 & 8.19 & 1.35 & 5.32 & 156 & 6.27 & 34.4 \\
\hline
\end{tabular}

\section{Results}

The calculated salinity values are $0.27-1.86 \%$ (average $0.78 \%$ ) in the dune sediments of the Taklamakan Desert, with pH values ranging from 8.66 to 9.54 (average 9.22) (Fig. 2a). For the dune sediments from the Badanjilin Desert, the $\mathrm{pH}$ and salinity values range between 8.82 and 9.42 (average 9.12) and $0.05 \%$ and $0.42 \%$ (average $0.15 \%$ ), respectively (Fig. $2 \mathrm{~b}$ ). The range of $\mathrm{pH}$ values between the aeolian sediments is narrow (8.6-9.5), suggesting generally similar alkaline soil conditions and buffer capacities. Because $\mathrm{pH}$ values in soil between 6.4-12.2 are mainly caused by bicarbonate (6.4-10.3) and carbonate (10.3-12.2) [36], consequently, the alkalinities of these aeolian salts are mainly determined by the carbon-bearing salts, particularly bicarbonate.

The major anions of aeolian salts are $\mathrm{HCO}_{3}{ }^{-}$and $\mathrm{Cl}^{-}$, and the $\mathrm{SO}_{4}{ }^{2-}$ concentrations are very low in all samples (Fig. 2d). The first major cation is $\mathrm{Na}^{+}$, followed by $\mathrm{Ca}^{2+}$, while the concentrations of $\mathrm{K}^{+}$and $\mathrm{Mg}^{2+}$ are low (Fig. 2e-f). The concentrations of the carbon-bearing ions in dune-surface sediments are positively correlated with the $\mathrm{pH}$ values (Fig. 2c). According to the major ion concentrations, the mineralogy of aeolian salts can be classified as follows: $\mathrm{NaHCO}_{3}+\mathrm{NaCl}+\left(\mathrm{CaCO}_{3}\right)$ in the Badanjilin Desert (Fig. 2g), and $\mathrm{NaCl}+\mathrm{NaHCO}_{3}$ in the Taklamakan Desert (Fig. 2h). It indicates that sodium carbonate and chloride are the common salts in aeolian sediments within the deserts of northwestern China. 
(a)

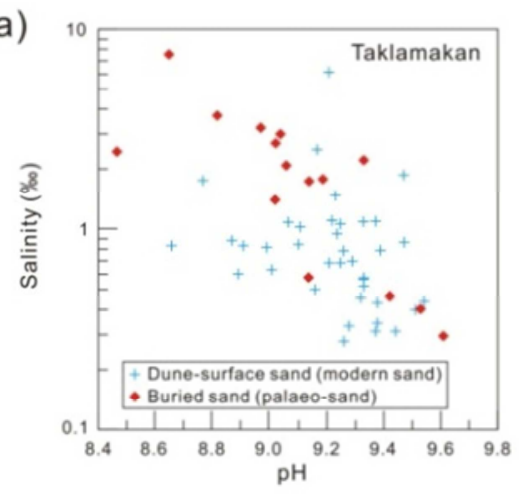

(d) (b)

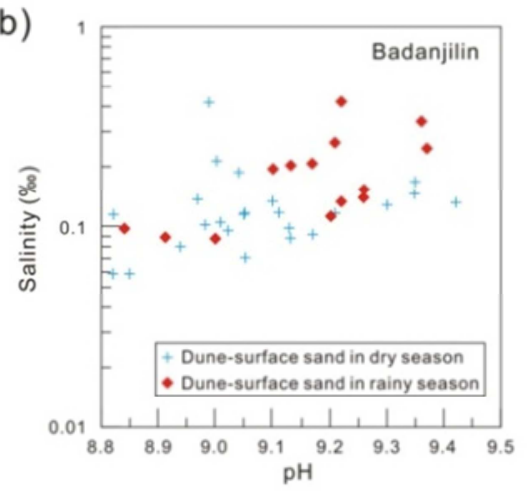

(e)

+ Badanjilin

- Taklamakan

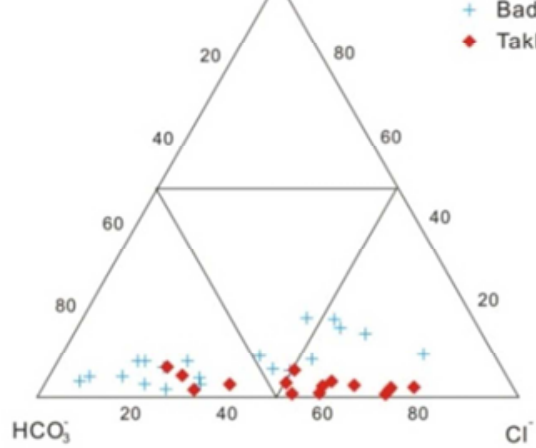

(g)
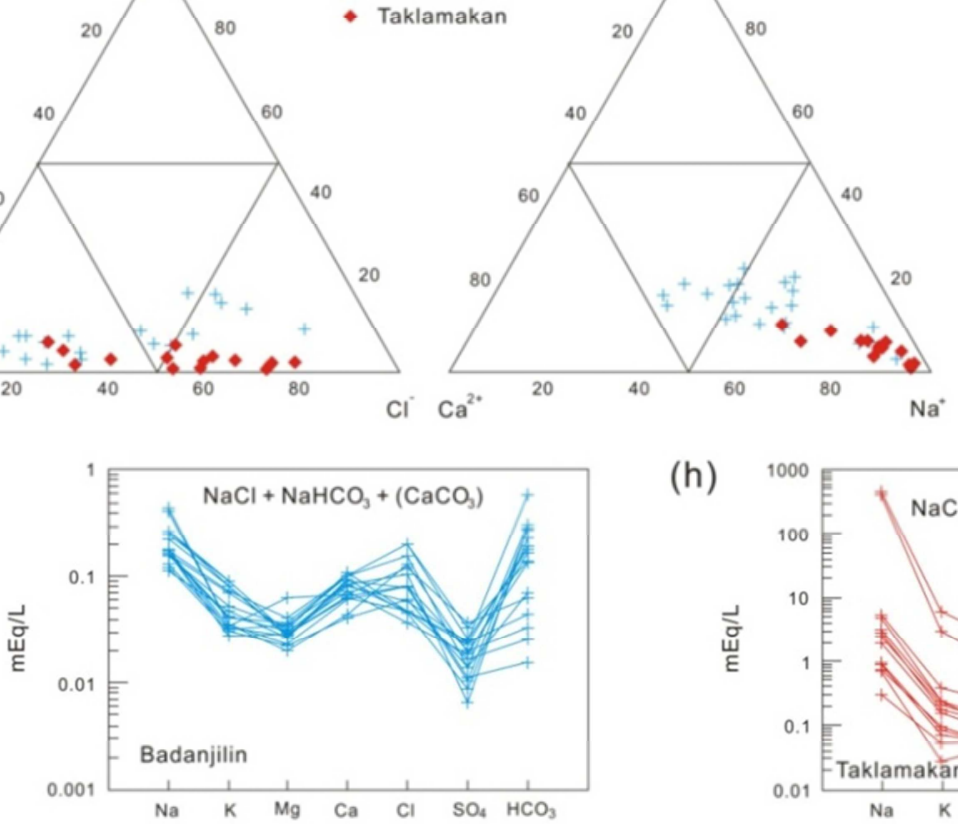

(h) (c)

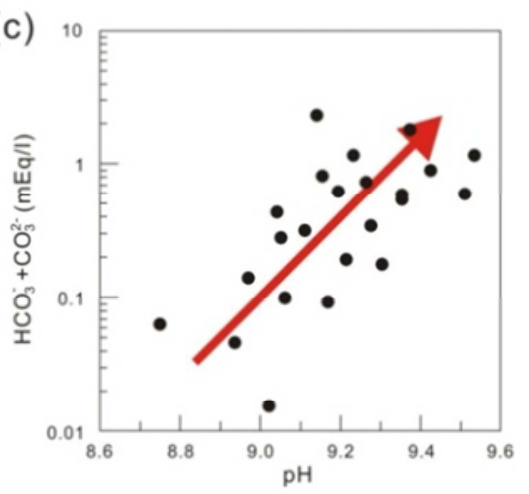

(f)
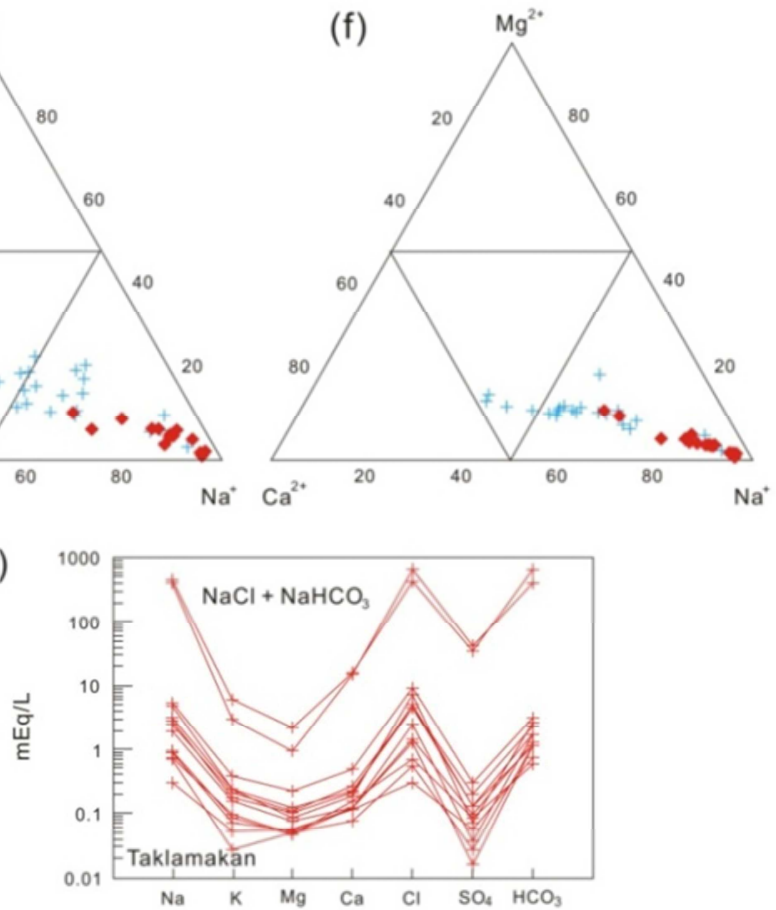

Figure 2. Salinities and major compositions of sediment solutions, (a) dune-surface sediments (modern sediment) and buried-dune sediments (palaeo-sediment) in the Taklamakan Desert, (b) dune-surface sand samples collected in different climatic seasons (dry and wet) in the Badanjilin Desert. (c) Carbon-bearing ions vs. pH. Triangular plots of major anions (d) and cations ( $e$ and f) of the soluble salts in mEq/l unit. Distribution patterns of the major ions of the soluble salts in the aeolian sediments from $(g)$ the Badanjilin Desert and from (h) the Taklamakan Desert.

\section{Discussion}

\subsection{Secondary Salt}

It is firstly necessary to understand whether the nature of soluble salt in aeolian sediment is primary or secondary in origin.

As defined by Warren (2006) [4], a salt deposit (evaporite) is originally precipitated from a saturated surface or nearsurface brine by hydrologies, driven by solar evaporation. It means that primary salts are precipitated from a standing body of surface brine and retaining crystallographic evidence of the depositional process. According to this definition, almost every subsurface salt texture is secondary, because it is diagenetically altered, frequently with fabrics indicating pervasive early recrystallization. Secondary salts can be formed in surface/subsurface settings equivalent to the eogenetic, mesogenetic and telogenetic realms [37].
Under this definition of a primary versus secondary salt, we can say that, outside of a few Neogene examples [38, 39, 40, 41], there are few salt deposit with textures that are wholly and completely "primary". Without exception, soluble salts in aeolian sediments should be secondary salt originated in the eogenetic realm.

Besides, studies in Chinese deserts that focusing on sediment/soil carbonate $\delta^{13} \mathrm{C}$, which can establish strategies for determining the provenance and formation of these carbonates, have proposed that the carbonates in the middle-latitude Chinese deserts are enriched in carbon isotope, with positive $\delta^{13} \mathrm{C}$ values around or above $0 \%$ [42, 43]. Because $\mathrm{CO}_{2}$ absorption/degassing, in combination with evaporation and rapid microbial growth, can drive extreme carbon isotope enrichment [44], it further suggests that the carbonates in aeolian sediments from Chinese deserts are secondary salt in origin. 


\subsection{Evaporitic Alkaline Earth Carbonates and Syndepositional Process}

Salt minerals can be simply subdivided into evaporitic alkaline earth carbonates and evaporite salts [4]. Evaporitic alkaline earth carbonates are the first salt minerals to precipitate from a concentrating hypersaline surface water and they are tend to form in the initial/early stages of brine concentration, while the other evaporitic salts are precipitated in the more saline stages of concentration [45]. As analyzed above in this study, $\mathrm{NaHCO}_{3}+\mathrm{CaCO}_{3}$ are the common salts in aeolian sediments within both the Taklamakan and the Badanjilin Deserts. It indicates that evaporitic alkaline earth carbonates are major component of these aeolian salts.

Although texture of most of the soluble salts is secondary, these secondary salts are often syndepositional precipitates, forming cements and replacement even as the primary matrix accumulates around them [4]. For aeolian sediments in arid environment, we image that much of surface salts are deposited in multiple episodes of early diagenetic (syndepositional) cementation. This syndepositional salt may be formed in multiple dissolution-precipitation events in the sand particle surface and are precipitated between successive depositional episodes of salt crust formation.

\subsection{Potential Role of Aeolian Carbon Salts in PIC Pool}

According to the analysis above, evaporitic alkaline earth carbonate salts $\left(\mathrm{NaHCO}_{3}+\mathrm{CaCO}_{3}\right)$ are a prominent component of aeolian salts in the Taklamakan and Badanjilin Deserts, two of the largest middle-latitude deserts where much of the Asian dust is produced $[13,43]$. Because soluble salts in aeolian sediments are mainly atmospheric origin [16, 17], and conversely dust from Asian deserts can affect global atmospheric chemical processes and aerosol characteristics due to the acid neutralizing capacity of this species [46], it thus can say that aeolian carbon salts in the Chinese deserts are a potential component of global PIC pool. Evaluating the role of aeolian salts in PIC pool and its dynamics is important to understanding the global carbon cycle.

Stone (2008) [25] has suggested that a significant loop in the carbon cycle may be hidden in the global desert areas. According to the hypothesis of Stone (2008) [25], it implies that a desert region would provide a significant contribution for the global carbon cycle if it satisfies the following prerequisites: 1) it can fix the carbon in inorganic-salt form from the atmosphere, 2) the acid-buffering capacity of the soil is large, 3) its area is large enough so that the quantity of carbon fixed can be noticeable on a global scale and 4) the fixed carbon can be conserved in the soil.

There is little vegetation (herbs, shrubs, trees and lianas as $\mathrm{C} 3$ and $\mathrm{C} 4$ plants) in the Taklamakan and Badanjilin deserts due to their hyper-arid climate, and the $\delta^{13} \mathrm{C}$ values dominated by carbonates are produced by atmospheric deposition [42, 43], thus the alkaline earth carbonate salts in aeolian sands are closely related to atmospheric $\mathrm{CO}_{2}$ absorption. This means that the elemental carbon in aeolian salts is introduced from the atmosphere into the pedosphere by a carbon-fixation process

Alkalinity is a key buffer for neutralizing the hydrogen ion $\left(\mathrm{H}^{+}\right)$[36], meaning that a degree of soil alkalinity has a potential capability to neutralize atmospheric carbonic acid. The ground surface conditions of the Taklamakan and Badanjilin Deserts in northwestern China are alkaline and these alkalinities result from the presence of the carbonates. This is evidenced by the relatively high $\mathrm{pH}$ values (8.4-9.6) of the surface dune sands (On-line Supplementary Table 1) and the positive correlation between $\mathrm{pH}$ and the content of carbon-bearing salts (Fig. 2c). The increase in carbonate contents together with the increase in $\mathrm{pH}$ values in the aeolian sediments (Fig. 2c) indicates that the potential capacity of atmospheric carbon fixation in soil also increases. The reaction with atmospheric $\mathrm{CO}_{2}$ would consume the alkalinity within a relatively short period under humid conditions. There has to be a long acting source. Calcium carbonate can rapidly precipitate during drought conditions, that is, when both soil moisture and root activity are low, and more generally, carbonate typically accumulates in soils where the mean annual precipitation is less than $1000 \mathrm{~mm}$ yr-1 [47].

The summary area of the Taklamakan and the Badanjilin deserts in northwestern China, about $386,000 \mathrm{~km}^{2}$, accounts for about one third (32\%) of the total area of the global mid-latitudes sandy deserts, undoubtedly a noticeable body on a global scale.

In humid environments, soil carbonate is subjected to leaching, but when mean annual precipitation is limited to approximately $500 \mathrm{~mm}[48,49]$, at least a portion of soil carbonate accumulates in the soil profile. In this way, carbonate in desert soils may provide a sink for atmospheric $\mathrm{C}$ $[3,50,51,52]$. Regarding the balance between the eluviation and the precipitation processes for the desert environment in northwestern China, the mean annual precipitation rates in this land are less than $400 \mathrm{~mm}$ in most cases (Fig. 1a), namely the deserts of northwestern China are almost located in areas below the $400 \mathrm{~mm}$ isohyet, thus resulting a more strong precipitation process than an eluviations process. In continental scale, mean annual precipitation tends to increase from west to east in northern China. This is supported by the observation that the carbonate content of surface soils in northern China varies inversely with mean annual precipitation $[53,43]$. This kind of couples between moisture and salt distribution patterns indicates that the carbon salts in the desert soil across the two Chinese deserts has the nature to be preserved in the soil. Within the past several dozen of years, desertification induced by human activities may have caused over a $40 \%$ loss of total carbon storage (including organic) in the desert lands of northwestern China [14, 54], however, our works have proved that a considerable amount of this carbon was re-deposited downwind of the desert rather than being released into the atmosphere [14]. All these mean that the fixed carbon in the desert can be finally conserved in the soil.

The analysis confirms that the aeolian sediments in the wide desert regions of northwestern China, the large middle-latitude deserts in northern Hemisphere, can fix atmospheric carbon in an inorganic-salt form with a 
significant acid-buffering capacity, due to their strong alkalinity. This evidence strongly implies that the two Chinese deserts potentially qualify as significant contributors to the global carbon cycle. This is, to a great extent, similar to the Gulbantonggut Desert in northwestern China and the Mojave Desert in the USA [25], both of which are key regions for the global carbon cycle in the mid-latitudes of the Northern Hemisphere. However, the author of this paper think that the low-latitude deserts in tropic areas are not capable of providing such a contribution for the global carbon cycle as proposed by Stone (2008)[25], because the tropic deserts could not satisfy entirely the four prerequisites mentioned above in this study, since the compositions of soil inorganic salts in these deserts are sulphate- or chloride-rich (not carbonate-rich), such as chloride-sulfate salts dominated in the Kalahari Desert [55], and the degree of soil alkalinity is not high (pH 6.9 8.1, [56]).

\section{Conclusion}

Due to the complexity of salt formation involved in atmosphere-landscape relation, there are few study involved into the pool of secondary carbonates in world desert soils, particularly in arid areas in northern China. In this work we carried out a physical and geochemical exploration into soluble carbon salts in dune sediments from the inland deserts (the Taklamakan and the Badanjilin Deserts) in northwestern China to explore the composition and distribution of evaporitic carbon salts in aeolian sediments and their possible environmental implications for global carbon cycle. The results show that the aeolian salt has high alkalinities, which are mainly determined by evaporitic alkaline earth bicarbonates. The carbonates are secondary salt in origin and are possibly introduced from the atmosphere into the pedosphere by a carbon-fixation process. Due to the high capability to neutralize atmospheric carbonic acid, large desert area, and the strong potential of carbonate accumulation in soil under arid climate, the middle-latitude Chinese deserts can be potentially qualified as a significant contributor to the global carbon cycle. But the low-latitude deserts in tropic areas are maybe not able to provide such a contribution.

\section{Acknowledgments}

This work was supported by Foundations from China (Grant no.: NKRDP 2016YFA0601901 and 2016YFA0601904, NSFC 41371060, IGSNRR 2013RC101, NSFC 41225001 and 41671198). The author is grateful to Prof. Xiaoping Yang for his generous help in the research work.

\section{References}

[1] Eswaran, H., Reich, P. F., Kimble, J. M., Beinroth, F. H., Padmanabhan, E., Moncharoen, P. (2000). Global carbon stocks. In: Lal, R., Kimble, J. M., Eswaran, H., Stewart, B. A. (eds) Global Climate Change and Pedogenic Carbonates. CRC Press LLC, Boca Raton, pp 15-25.
[2] Lal, R., Kimble, J. M. (2000). Pedogenic carbonates and the global carbon cycle. In: Lal, R., Kimble, J. M., Eswaran, H., Stewart, B. A. (eds) Global Climate Change and Pedogenic Carbonates. CRC Press LLC, Boca Raton, pp 1-14.

[3] Kraimer, R. A., Monger, H. C., Steiner, R. L. (2005). Mineralogical distinctions of carbonates in desert soils. Soil Science Society of America Journal, 69, 1773-1781.

[4] Warren, J. K. (2006). Evaporites: sediments, resources and hydrocarbons. Springer, Berlin.

[5] Batjes, N. H., Sombroek, W. G. (1997). Possibilities for carbon sequestration in tropical and subtropical soils. Global Change Biology, 3, 161-173.

[6] Adams, J. M., Post, W. M. (1999). A preliminary estimate of changing calcrete carbon storage on land since the last glacial maximum. Global and Planetary Change, 20, 243-256.

[7] Pal, D. K., Dasog, G. S., Vadivelu, S., Ahuja, R. L., Bhattacharyya, T. (2000). Secondary calcium carbonate in soils of arid and semiarid regions of India. In: Lal, R., Kimble, J. M., Eswaran, H., Stewart, B. A. (Eds) Global Climate Change and Pedogenic Carbonate. CRC Press LLC, Boca Raton, pp 149-185.

[8] Emmerich, W. E. (2003). Carbon dioxide fluxes in a semiarid environment with high carbonate soils. Agricultural and Forest Meteorology, 116, 91-102.

[9] Lal, R. (2004). Soil carbon sequestration impacts on global climate change and food security. Science, 304, 1623-1627.

[10] Canadell, J. G., Quere, C. L., Raupach, M. R., Field, C. B., Buitenhuis, E. T., Ciais, P., Conway, T. J., Gillett, N. P., Houghton, R. A., Marland, G. (2007). Contributions to accelerating atmospheric $\mathrm{CO}_{2}$ growth from economic activity, carbon intensity, and efficiency of natural sinks. Proceedings of National Academy of Sciences of the United States of America, 104, 18866-18870.

[11] Duan, Z., Xiao, H., Dong, Z., He, X., Wang, G. (2001). Estimate of total $\mathrm{CO}_{2}$ output from desertified sandy land in China. Atmospheric Environment, 35, 5915-5921.

[12] Feng, Q., Cheng, G., Masao., M. (2002a). The carbon cycle of sandy lands in China and its global significance. Climatic Change, 48, 535-549.

[13] Feng, Q., Endo, K. N., Cheng, G. D. (2002b). Soil carbon in desertified land in relation to site characteristics. Geoderma, $106,21-43$.

[14] Yang, X., Zhu, B., Wang, X., Li, C., Zhou, Z., Chen, J., Wang, X., Yin, J., Lu, Y. (2008). Late Quaternary environmental changes and organic carbon density in the Hunshandake Sandy Land, eastern Inner Mongolia, China. Global and Planetary Change, 61, 70-78.

[15] Wu, H., Guo, Z., Gao, Q., Peng, C. (2009). Distribution of soil inorganic carbon storage and its changes due to agricultural land use activity in China. Agriculture, Ecosystems and Environment, 129, 413-421.

[16] Zhu, B., Yang, X. (2010). The origin and distribution of soluble salts in the sand seas of northern China. Geomorphology, 123, 232-242. 
[17] Zhu, B., Yang, X., Liu, Z., Rioual, P., Li, C., Xiong, H. (2012). Geochemical compositions of soluble salts in aeolian sands from the Taklamakan and Badanjilin deserts in northern China, and their influencing factors and environmental implications. Environmental Earth Sciences, 66, 337-353.

[18] Schimel, D., House, J., Hibbard, K. (2001). Recent patterns and mechanisms of carbon exchange by terrestrial ecosystems. Nature, 414, 169-172.

[19] Steven, C. W. (2001). Climate change enhanced: where has all the carbon gone. Science, 292, 2261-2263.

[20] Houghton, R. A. (2007). Balancing the global carbon budget. Annual Review of Earth and Planetary Sciences, 35, 313-347.

[21] Ballantye, A. P., Alden, C. B., Miller, J. B., Tan, P. P., White, J. W. (2012). Increase in observed net carbon dioxide uptake by land and oceans during the past 50 years. Nature, 488, 70-72.

[22] Evans, R. D., et al. (2014) Great ecosystem carbon in the Mojave Desert after ten years exposure to elevated $\mathrm{CO}_{2}$. Nature Climate Change, 4, 394-397.

[23] Li, Y., Wang, Y. G., Houghton, R. A., Tang, L. S. (2015). Hidden carbon sink beneath desert. Geophysical Research Letters, 42, 5880-5887.

[24] Jasoni, R. L., Smith, S. D., Arnone, J. A. (2005). Net ecosystem $\mathrm{CO}_{2}$ exchange in Mojave Desert shrublands during the eighth year of exposure to elevated $\mathrm{CO}_{2}$. Global Change Biology, 11, 749-756.

[25] Stone, R. (2008). Have Desert researchers discovered a hidden loop in the Carbon Cycle. Science, 320, 1409-1410.

[26] Wohlfahrt, G., Fenstermaler, L., Arnone, J. A. (2008). Large annual net ecosystem $\mathrm{CO}_{2}$ uptake of a Mojave Desert ecosystem. Global Change Biology, 14 (7), 1475-1487

[27] Xie, J., Li, Y., Zhai, C., Li, C., Lan, Z. (2009). $\mathrm{CO}_{2}$ absorption by alkaline soils and its implication to the global carbon cycle. Environmental Geology, 56, 953-961.

[28] Ma, J., Liu, R., Tang, L. S., Lan, Z. D., Li, Y. (2014). A downward $\mathrm{CO}_{2}$ flux seems to have nowhere to go. Biogeosciences, 11, 6251-6262.

[29] Yang, Y., Fang, J., Ji, C., Ma, W., Su, S., Tang, Z. (2010) Soil inorganic carbon stock in the Tibetan alpine grasslands. Global Biogeochemical Cycles, 24, GB4022, doi:10.1029/2010GB003804.

[30] Shi, Y., Baumann, F., Ma, Y., Song, C., Kuhn, P., Scholten, T., He, J. S. (2012). Organic and inorganic carbon in the topsoil of the Mongolian and Tibetan grasslands: pattern, control and implications. Biogeosciences, 9, 2287-2299.

[31] Liu W, Wei J, Cheng J, Li W (2014) Profile distribution of soil inorganic carbon along a chronosequence of grassland restoration on a 22-year scale in the Chinese Loess Plateau. Catena, 121: 321-329.

[32] Tan, W., Zhang, R., Huang, C., Yang, Q., Wang, M., Koopal, L. K. (2014). Soil inorganic carbon stock under different soil types and land uses on the Loess Plateau region of China. Catena, 121, 22-30.

[33] Yang, Z. C., Zhao, N., Huang, F., Lv, Y. Z. (2015). Long-term effects of different organic and inorganic fertilizer treatments on soil organic carbon sequestration and crop yields on the North China Plain. Soil and Tillage Research, 146, 47-52.

[34] Zhao, W., Zhang, R., Huang, C., Wang, B., Cao, H., Koopal, L. K., Tan, W. (2016) Effect of different vegetation cover on the vertical distribution of soil organic and inorganic carbon in the Zhifanggou Watershed on the loess plateau. Catena, 139, 191-198.

[35] Li, C., Zhao, L., Ge, S., Chen, D., Dong, Q., Zhao, X. (2016). Land-use effects on organic and inorganic carbon patterns in the topsoil around Qinghai Lake basin, Qinghai-Tibetan Plateau. Catena, 147, 345-355.

[36] Wetzel, R. G., Likens, G. E. (2000). Limnological analyses, 3rd edn. Springer, New York.

[37] Choquette, P. W., Pray, L. C. (1970). Geological nomenclature and classification of porosity in sedimentary carbonates. Bulletin American Association of Petroleum Geologists, 54, 207-250.

[38] Riding, R., Braga, J. C., Martin, J. M., Sanchezalmazo, I. M. (1998). Mediterranean Messinian salinity crisis - constraints from a coeval marginal basin, Sorbas, southeastern Spain. Marine Geology, 146, 1-20.

[39] Valero-Garces, B. L., Arenas, C., Delgado-Huertas, A. (2001). Depositional environments of Quaternary lacustrine travertines and stromatolites from high-altitude Andean lakes, northwestern Argentina. Canadian Journal of Earth Sciences, $38,1263-1283$.

[40] Valero-Garces, B. L., Delgado-Huertas, A., Ratto, N., Navas, A. (1999). Large C-13 enrichment in primary carbonates from Andean Altiplano lakes, northwestern Argentina. Earth and Planetary Science Letters, 171, 253-266.

[41] Pedley, M., Martin, J. A. G., Delgado, S. O., Del, Cura, D. (2003). Sedimentology of Quaternary perched springline and paludal tufas: criteria for recognition, with examples from Guadalajara Province, Spain. Sedimentology, 50, 23-44.

[42] Wen, Q. Z. (1989). Chinese loess geochemistry. Science Press, Beijing (in Chinese).

[43] Wang, Y. Q., Zhang, X. Y., Arimoto, R., Cao, J. J., Shen, Z. X. (2005). Characteristics of carbonate content and carbon and oxygen isotopic composition of northern China soil and dust aerosol and its application to tracing dust sources. Atmospheric Environment, 39, 2631-2642.

[44] Schouten, S., Hartgers, W. A., Lopez, J. F., Grimalt, J. O., Damste, J. S. S. (2001). A molecular isotopic study of C-13-enriched organic matter in evaporitic deposits: recognition of $\mathrm{CO}_{2}$-limited ecosystems. Organic Geochemistry, 32, 277-286.

[45] Smoot, J. P., Lowenstein, T. K. (1991). Depositional environments of non-marine evaporites. In: Melvin, J. L. (ed) Evaporites, Petroleum and Mineral Resources. Elsevier, Amsterdam, pp 189-347.

[46] Dentener, F. J., Carmichael, G. R., Zhang, Y. (1996). The role of mineral aerosols as a reactive surface in the global troposphere. Journal of Geophysical Research, 101, 22869-22889.

[47] Jenny, H. (1980). The soil resource. Springer, New York. 
[48] Marion, G. M., Schlesinger, W. H., Fonteyn, P. J. (1990). Spatial variability of $\mathrm{CaCO}_{3}$ solubility in a Chihuahuan Desert soil. Arid Soil Research and Rehabilitation, 4, 181-191.

[49] Birkeland, P. W. (1999). Soils and Geomorphology. Oxford University Press, New York.

[50] Scharpenseel, H. W., Mtimet, A., Freytag, J. (2000). Soil inorganic carbon and global change. In: Lal, R., Kimble, J. M., Eswaran, H., Stewart, B. A. (eds) Global Climate Change and Pedogenic Carbonates. CRC Press LLC, Boca Raton, pp 27-42.

[51] Monger, H. C., Martinez-Rios, J. J. (2000). Inorganic carbon sequestration in grazing lands. In: Follet, R. F. (ed) The Potential of U.S. Grazing Lands to Sequester carbon and mitigate the greenhouse effect. CRC Press LLC, Boca Raton, pp 87-118.
[52] Monger, H. C., Gallegos, R. A. (2000). Biotic and abiotic processes and rates of pedogenic carbonate accumulation in the southwestern United States - relationship to atmospheric $\mathrm{CO}_{2}$ sequestration. In: Lal, R., Kimble, J. M., Eswaran, H., Stewart, B. A. (eds) Global Climate Change and Pedogenic Carbonates. CRC Press LLC, Boca Raton, pp 273-289.

[53] Zhu, Z., Wu, Z., Liu, S., Di, X. (1980). An outline of Chinese sandy deserts. Science Press, Beijing (in Chinese).

[54] Wang, T. (2003). Desert and Desertification in China. Hebei Science and Technology Press, Shijiazhuang (in Chinese).

[55] Wang, L., D’Odorico, P., Okin, G., Macko, S. (2009). Isotope composition and anion chemistry of soil profiles along the Kalahari Transect. Journal of Arid Environments, 73, 480-486.

[56] Petrov, M. P. (1976). Deserts of the world. John Wiley \& Sons, New York. 